\title{
NOTES
}

\section{Streptococcus lactis subsp. cremoris (Orla-Jensen) comb. nov. and Streptococcus lactis subsp. diacetilactis (Matuszewski et al.) nom. rev., comb. nov.}

\author{
ELLEN I. GARVIE AND JOHN A. E. FARROW
}

National Institute for Research in Dairying, Shinfield, Reading RG2 9AT, England

\begin{abstract}
Streptococcus lactis (Lister 1873) Löhnis 1909 and Streptococcus cremoris Orla-Jensen 1919 have a number of significant properties in common and belong to the same DNA homology group. $S$. cremoris is here regarded as a subspecies of $S$. lactis. The name of the subspecies is S. lactis subsp. cremoris (Orla-Jensen) comb. nov. Streptococcus diacetilactis Matuszewski et al. 1936 does not appear on the approved lists of bacterial names (Int. J. Syst. Bacteriol. 30:225-420, 1980). However, it is here regarded as a recognizable taxon, for which the name $S$. lactis subsp. diacetilactis (Matuszewski et al.) nom. rev., comb. nov. is proposed. The type strain of this subspecies is NCDO 176.
\end{abstract}

The status of Streptococcus cremoris OrlaJensen 1919 as a species different from Streptococcus lactis (Lister 1873) Löhnis 1909 (12) has been questioned $(4,7,10)$. Lawrence et al. (10) stated, "It remains to be seen if differences in genetic homology can be used to distinguish between the three species." (The third was called Streptococcus diacetilactis.) The specific epithet lactis dates back to Lister (11), and the name $S$. cremoris dates to Orla-Jensen (14). The criteria then available permitted differentiation of the two species, and it is only in recent years, as knowledge of the metabolism and the structure and function of cell components of bacteria has increased, that doubts have arisen about the classification of these organisms. The status of $S$. lactis subsp. diacetilactis is different. It was first named in 1936 (13), but studies by Swartling (17) and Zielinska and Hiscox (18) in the early 1950 s showed many similarities to $S$. lactis. Thus, Deibel and Seeley (3) gave subspecies rank to the bacterium previously named $S$. diacetilactis. This was, however, not on the approved lists of bacterial names (16).

The question posed by Lawrence et al. (10) has been answered recently, and it is now known that $S$. lactis, $S$. lactis subsp. diacetilactis, and $S$. cremoris belong to a single DNA homology group $(5,6)$. The DNAs of $S$. cremoris strains are 75 to $100 \%$ homologous with the DNA of the type strain of $S$. lactis, NCDO 604, and a starter strain, NCDO 712 . The percentage of homology between the DNAs of $S$. lactis NCDO 604 and the type strain of $S$. cremoris, NCDO 607 , is $78 \%$. Similarly, there is over $80 \%$ homology between strains of S. lactis subsp. diacetilactis and the type strain of S. lactis (5, 6).

There is no universally accepted definition of a bacterial species, and the criteria generally used are uneven, but strains with a high DNA homology form a natural unit. Within a DNA homology group, strains differentiated by physiological properties should be subspecies. On this basis, $S$. cremoris would be a subspecies of $S$. lactis. Table 1 shows properties of the three above-mentioned taxa as previously described $(3,5,17,18)$. Other characters presently used in bacterial taxonomy have failed to separate $S$. lactis from $S$. cremoris and have supported the subspecies rank of $S$. lactis subsp. diacetilactis. Schleifer and Kandler (15) found that the interpeptide bridges of the cell walls of $S$. lactis and $S$. cremoris contain L-lysine D-asparagine, a composition rarely found in streptococci, except for Streptococcus faecium. The lactate dehydrogenases of $S$. lactis, $S$. lactis subsp. diacetilactis, and $S$. cremoris have similar properties (5) which have not been found in any other species, not even in some which are phenotypically similar to $S$. lactis but which belong to a different DNA homology group. The structures of the isoprenoid quinones found in S. lactis, $S$. lactis subsp. diacetilactis, and $S$. cremoris are similar but are not found in many streptococcal species (2). As would be expected within a DNA homology group, the guanine plus cytosine contents of the DNAs of the members of the group come within a narrow range; the values for strains NCDO 604 and NCDO 607 are 35.8 and 
TABLE 1. Selected properties of S. lactis subsp. lactis, S. lactis subsp. diacetilactis, and S. cremoris

\begin{tabular}{|c|c|c|c|c|c|c|}
\hline \multirow[b]{2}{*}{ Determination } & \multicolumn{4}{|c|}{ S. lactis } & \multicolumn{2}{|c|}{ S. cremoris } \\
\hline & $\begin{array}{l}\text { Type strain } \\
\text { NCDO } 604\end{array}$ & $\begin{array}{l}\text { Nondairy } \\
\text { strains }\end{array}$ & $\begin{array}{c}\text { Dairy } \\
\text { strains }\end{array}$ & $\begin{array}{l}\text { S. lactis subsp. } \\
\text { diacetilactis }\end{array}$ & $\begin{array}{l}\text { Type strain } \\
\text { NCDO } 607\end{array}$ & Species \\
\hline Growth at $10^{\circ} \mathrm{C}$ & + & + & + & + & + & + \\
\hline $40^{\circ} \mathrm{C}$ & + & + & + & + & - & + \\
\hline $45^{\circ} \mathrm{C}$ & - & - & - & - & - & - \\
\hline Growth in $2 \% \mathrm{NaCl}$ & + & + & + & + & + & + \\
\hline $4 \%$ & + & + & + & + & - & - \\
\hline $6.5 \%$ & - & - & - & - & - & - \\
\hline Hydrolysis of arginine & + & + & + & \pm & - & - \\
\hline Utilization of citrate & - & - & - & + & - & \pm \\
\hline \multicolumn{7}{|l|}{ Acid from: ${ }^{a}$} \\
\hline Arabinose & - & - & - & - & - & - \\
\hline Ribose & . & + & + & . & . & - \\
\hline Xylose & + & . & - & - & - & - \\
\hline Cellobiose & - & . & + & . & . & - \\
\hline Lactose & + & \pm & + & + & + & + \\
\hline Maltose & + & + & + & + & - & - \\
\hline Sucrose & - & \pm & \pm & - & - & $\mp$ \\
\hline Trehalose & + & \pm & + & \pm & - & $\mp$ \\
\hline Raffinose & - & \pm & - & - & - & - \\
\hline Dextrin & + & + & + & + & - & - \\
\hline
\end{tabular}

${ }^{a}$ All strains fermented fructose, galactose, glucose, and usually aesculin and salicin. No strains fermented sorbose, rhamnose, melibiose, melezitose, polysaccharides, or alcohols, except mannitol, which was not fermented by $S$. cremoris but which was fermented by some strains of $S$. lactis. Results with NCDO 604 were variable. Symbols: + , positive; - , negative; \pm , most strains positive, but some negative; $\mp$, most strains negative, but some positive.

35.4 mol\% (5), respectively. (The type strain of $S$. lactis subsp. diacetilactis has not been examined.) These values are at the lower end of the guanine plus cytosine range for streptococci.

These properties, common to $S$. lactis and $S$. cremoris, might be considered more significant taxonomically than the phenotypic differences. For commercial reasons it is important to distinguish $S$. cremoris as a distinct entity, and its many differences from $S$. lactis subsp. lactis must be taken into account. It is proposed, therefore, that $S$. cremoris be reclassified as $S$. lactis subsp. cremoris (Orla-Jensen) comb. nov.

$S$. lactis subsp. lactis resembles $S$. lactis subsp. diacetilactis more closely than it resembles $S$. cremoris. The main difference is that $S$. lactis subsp. diacetilactis can use citrate (1). This property is so important commercially that the identity of $S$. lactis subsp. diacetilactis should be retained. The ability to use citrate is a variable property and is plasmid linked, but only the permease and not the citritase is coded as a plasmid $(5,8)$.

$S$. lactis is a typical streptococcus, i.e., it is a gram-positive, catalase-negative coccus or coccoid rod dividing in one plane to form chains of cells. The chains are often short. S. lactis can be distinguished from other streptococci because it grows at $10^{\circ} \mathrm{C}$ but not at $45^{\circ} \mathrm{C}$. The temperature for optimum growth is 22 to $30^{\circ} \mathrm{C}$. It does not grow in the presence of $6.5 \% \mathrm{NaCl}$ or at $\mathrm{pH} 9.6$. Lactose-fermenting strains reduce litmus in litmus milk before acidifying and clotting the milk. Its lactate dehydrogenase has a high affinity for fructose-1,6-diphosphate and a wide range of $\mathrm{pH}$ activity; the enzyme is inhibited by phosphate, giving a typical reaction curve in in vitro tests $(4$, $5)$. The interpeptide bridge of the cell wall consists of L-lysine D-asparagine. Isoprenoid quinone structures have been identified in cells. The guanine plus cytosine content of the DNA is 34.4 to $35.8 \mathrm{~mol} \%$. The properties of $S$. lactis subsp. lactis are given in Table 1. It differs from $S$. lactis subsp. cremoris in that it grows at $40^{\circ} \mathrm{C}$ and in the presence of $4 \% \mathrm{NaCl}$, hydrolyzes arginine, and ferments maltose and dextrin. It is found in milk and dairy products and also on vegetable matter. $S$. lactis subsp. cremoris is less active than the type subspecies. Its properties are presented in Table 1 . It is found in dairy starter and dairy products and probably does not exist outside of these habitats.

Descriptions of $S$. lactis subsp. diacetilactis have been given by Swartling (17) and by Zie- 
linska and Hiscox (18); the latter include the type strain, NCDO 176, as strain 2. According to rule 46 of the Bacteriological Code (9), the valid publication of the names of $S$. lactis subsp. diacetilactis (Matuszewski, Pikanowski, and Supinska) comb. nov. and $S$. lactis subsp. cremoris (Orla-Jensen) comb. nov. automatically creates the subspecies $S$. lactis subsp. lactis. The type strains of these subspecies are NCDO 176, NCDO 607, and NCDO 604, respectively.

\section{REPRINT REQUESTS}

Address reprint requests to: John A. E. Farrow, National Institute for Research in Dairying, Shinfield, Reading RG2 9AT, England.

\section{LITERATURE CITED}

1. Collins, E. B., and R. J. Harvey. 1962. Failure in the production of citrate permease by Streptococcus diacetilactis. J. Dairy Sci. 45:32-35.

2. Collins, M. D., and D. Jones. 1979. The distribution of isoprenoid quinones in streptococci of serological groups D and N. J. Gen. Microbiol. 114:27-33.

3. Deibel, R. H., and H. W. Seeley, Jr. 1974. Family Streptococcaceae, p. 490-509. In R. E. Buchanan and N. E. Gibbons (ed.), Bergey's manual of determinative bacteriology, 8th ed. The Williams \& Wilkins Co., Baltimore.

4. Garvie, E. I. 1978. Streptococcus raffinolactis Orla-Jensen and Hansen, a group $\mathrm{N}$ streptococcus found in raw milk. Int. J. Syst. Bacteriol. 28:190-193.

5. Garvie, E. I., J. A. E. Farrow, and B. A. Phillips. 1981. A taxonomic study of some streptococci which grow at $10^{\circ} \mathrm{C}$ but not at $45^{\circ} \mathrm{C}$ including Streptococcus lactis and Streptococcus cremoris. Zentralbl. Bakteriol. 1 Abt. Orig. C 2:151-165.

6. Jarvis, A. W., and B. D. W. Jarvis. 1981. Deoxyribonu- cleic acid homology among lactic streptococci. Appl. Env. Microbiol. 41:77-83.

7. Jones, D. 1978. Composition and differentiation of the genus Streptococcus, p. 1-49. In F. A. Skinner and L. B. Quesnel (ed.), Streptococci. Academic Press, Inc. (London), Ltd. London.

8. Kempler, G. M., and L. L. McKay. 1979. Characterization of plasmid deoxyribonucleic acid in Streptococcus lactis subsp. diacetylactis: evidence for plasmid-linked citrate utilization. Appl. Env. Microbiol. 37:316-323.

9. Lapage, S. P., P. H. A. Sneath, E. F. Lessel, V. B. D. Skerman, H. P. R. Seeliger, and W. A. Clark (ed). 1975. International code of nomenclature of bacteria. American Society for Microbiology, Washington, D.C.

10. Lawrence, R. C., T. D. Thomas, and B. E. Terzaghi. 1976. Reviews on the progress of dairy science: cheese starters. J. Dairy Res. 43:141-193.

11. Lister, J. 1873. A further contribution to the natural history of bacteria and the germ theory of fermentative changes. Quart. J. Microbiol. Sci. 13:380-408.

12. Löhnis, F. 1909. Die benennung der milchsaürebakterien. Zentralbl. Bakteriol. Parasitenkd. Infektionskr. Hyg. Abt. 2 22:553-555.

13. Matuszewski, T., E. Pijanowski, and J. Supinska. 1936. Streptococcus diacetilactis $\mathrm{n}$. $\mathrm{sp}$. and its application to butter making. Pr. Zakl. Microbiol. Przem. Rosl. Warsz. 21:1-28.

14. Orla-Jensen, S. 1919. The lactic acid bacteria, p. 1-196. A. F. Høst \& Søns Forlag, Copenhagen.

15. Schleifer, K. H., and O. Kandler. 1972. Peptidoglycan types of bacterial cell walls and their taxonomic implications. Bacteriol. Rev. 36:407-477.

16. Skerman, V. B. D., V. McGowan, and P. H. A. Sneath. 1980. Approved lists of bacterial names. Int. J. Syst. Bacteriol. 30:225-420.

17. Swartling, P. F. 1951. Biochemical and serological properties of some citric acid fermenting streptococci from milk and dairy products. J. Dairy Res. 18:256-267.

18. Zielinska, M., and E. R. Hiscox. 1954. Aroma-producing group N streptococci isolated from cheddar cheese curd. J. Dairy Res. 21:238-244. 